Brit. J. vener. Dis. (1965), 41, 208.

\title{
SUBCLINICAL INFESTATION WITH WORMS IN SPECIAL CLINIC PATIENTS*
}

BY

\author{
PAMELA M. WRAY \\ Royal Hospital, Sheffield
}

Hookworm disease with anaemia has recently been the subject of leading articles in both the Lancet (1964) and the British Medical Journal (1964) following accounts by Salem and Truelove (1964) and by Gilles, Watson-Williams, and Ball (1964). This paper gives examples of worm infestation occurring without anaemia and with minimal symptomatology and seeks to alert physicians to the possibility of subclinical worm infestation.

\section{Material and Methods}

The faeces of 34 male and two female patients attending a Special Treatment Clinic in Sheffield were searched for parasites and ova; each patient was asked to bring specimens on three separate occasions. In some cases only one specimen was necessary to detect ova whilst other patients defaulted after only one specimen had been collected. The faeces were examined in the Public Health Laboratory by concentrating with hypertonic saline before microscopical search for ova. Cure was presumed when the faeces became ova-free on three occasions at weekly intervals.

\section{Results}

Thirteen of the 36 patients proved to be infested with worms:

Nine with Ankylostoma duodenale (hookworm) only;

Two with Ankylostoma duodenale and Trichuris trichiura (whipworm);

One with Trichuris trichiura alone;

One with Ascaris lumbricoides (roundworm) alone.

In five cases the ankylostome was detected on the first stool examination and in four cases on the second. The trichuris was detected in two cases on the first examination and in one case on the second. The ascaris was found in the first specimen examined.

Anaemia was not suspected clinically in any case. The haemoglobin was not estimated in all cases, but was above $13.9 \mathrm{~g} . / 100 \mathrm{ml}$. (95 per cent.) in twenty cases, seven of whom were worm-infested.

\footnotetext{
* Received for publication March 24, 1965.
}

The outstanding aspect of this small series of worm-infested cases was the lack of clinical features. Six of the thirteen positive cases had no sign or symptom of worm infestation. Seven had a clinical feature, such as protuberant abdomen, abdominal pain, diarrhoea, or anal irritation. It must be stressed that these symptoms were minimal and in the majority of cases were elicited only by careful questioning. Table I summarizes the clinical features in relation to worm infestation.

TABLE I

CLINICAL FEATURES

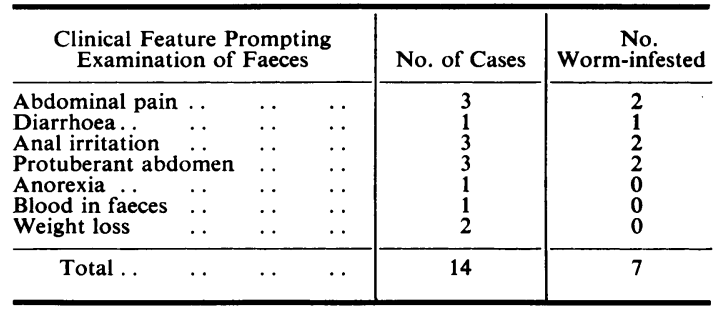

Disease other than worm infestation was present in nine of the thirteen positive cases and in 26 of the total 36 cases (Table II).

TABLE II

DISEASE OTHER THAN WORM-INFESTATION

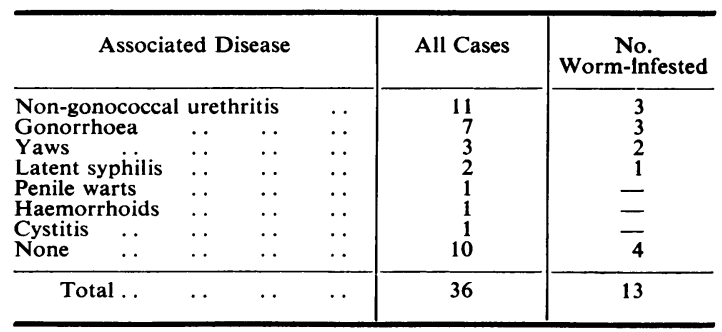

The majority of the patients were West Indian, but the series included patients from most immigrant countries; only one man was born in the United Kingdom. The country of origin of all cases and of the worm-infested cases is shown in Table III (opposite.) 
TABLE III

COUNTRY OF ORIGIN

\begin{tabular}{|c|c|c|c|c|}
\hline \multicolumn{3}{|c|}{ Country of Origin } & All Cases & No \\
\hline 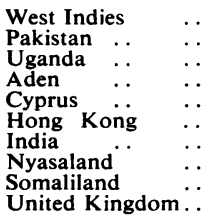 & $\begin{array}{l}. \\
\because \\
\because \\
\because \\
\cdots \\
\cdots \\
\cdots \\
\cdots \\
\cdots\end{array}$ & $\begin{array}{l}\cdots \\
\cdots \\
\cdots \\
\cdots \\
\cdots \\
\cdots \\
\cdots\end{array}$ & $\begin{array}{r}17 \\
10 \\
1 \\
2 \\
1 \\
1 \\
1 \\
1 \\
1 \\
1\end{array}$ & $\begin{array}{l}7 \\
5 \\
1 \\
= \\
= \\
= \\
=\end{array}$ \\
\hline Total ... & $\ldots$ & . & 36 & 13 \\
\hline
\end{tabular}

The ascaris was found in a Ugandan woman. Six of the ankylostome infestations were in male Jamaicans, and three in male Pakistanis. Double infestation with the ankylostome and the trichuris was present in one Jamaican and one Pakistani, both male. One male Pakistani had trichuris only.

\section{Discussion}

The results of this small survey indicate that infestation with worms, particularly the hookworm, is commoner in Great Britain than generally suspected. Out of 36 patients picked rather haphazardly from a Special Treatment Centre, thirteen proved to be infested though they had minimal presenting symptoms.

Nine of the thirteen had concomitant disease, but in four no other disease was detected. It is possible that the real incidence of infestation in this small series is higher than indicated, since eleven of the 26 negative cases had only one stool examination. Since many immigrants attend the Special Treatment Clinic before reporting to a general practitioner the venereologist is in a unique position to detect subclinical worm infestation. However, he is in a poor position in regard to the treatment if this small survey is representative; of the thirteen infested patients only nine can be counted cured, four defaulting while still infested.

Salem, Morcos, and El-Ninny (1965) reported an 85 per cent. cure rate with $5 \mathrm{~g}$. bephenium hydroxynaphthoate, pointing out that with this drug the heavier the infestation the higher the cure rate. In view of the paucity of symptoms, particularly the absence of anaemia in these cases, it seems likely that the infestation was comparatively light, but even mild infestation with worms can reduce the efficiency and wellbeing of the host and treatment should be advocated on this score.

It has been suggested (Brit. med. J., 1964) that hookworm infestation is not a public health problem in Great Britain, but the epidemic of hookworm anaemia in Cornish miners 60 years ago may belie this view (Manson-Bahr, 1960).
Summary and Conclusions

In a Special Treatment Centre in Sheffield, 36 patients with minimal presenting symptoms or none were investigated for worm infestation. Thirteen proved to be infested; nine with hookworm alone, two with hookworm and whipworm, one with whipworm alone, and one with round worm. Four of the thirteen cases had no other disease. Treatment was successful in nine cases; the rest defaulted before cure.

It is considered that infestation with worms, particularly the hookworm, is commoner in Great Britain than generally believed. Immigrant patients with minimal presenting symptoms should be screened to exclude such infestation.

I thank Dr E. H. Gillespie and his staff at the Public Health Laboratory, Sheffield, for the parasite examinations and Dr R. S. Morton, Sheffield, for encouragement in preparing this paper.

\section{ADDENDUM}

Since this article was written, the Public Health hazard of hook worm disease in Great Britain has been illustrated by the infestation in two Pakistani children, who were born in this country (Buckley and Pester, 1965). The parents of the children were not infected.

\section{REFERENCES}

British Medical Journal (1964). Leading article, 2, 1216 Buckley, J. J. C., and Pester, F. R. N. (1965). Ibid., 2, 106. Gilles, H. M., Watson-Williams, E. J., and Ball, P. A. J. (1964). Quart. J. Med., 33, 1.

Lancet (1964). Annotation, 2, 631.

Manson-Bahr, P. (1960). "Manson's Tropical Diseases", 15th ed., p. 790. Cassell, London.

Salem, H. H., Morcos, W. M., and El-Ninny, H. M. (1965). J. trop. Med. Hyg., 68, 21.

— and Truelove, S. C. (1964). Brit. med. J., 1, 1074.

Infestation par des vers parasites avec manifestations cliniques minimes chez des sujets atteints de maladies vénériennes.

RÉSUMÉ

Dans un centre de traitement des maladies vénériennes de Sheffield, 36 patients se présentant sans symptômes, ou avec des symptômes minimes, furent examinés dans le but de mettre en évidence une infestation par des vers parasites.

On prouva que treize d'entre eux étaient infestés, neuf par l'ankylostome seul, deux par l'ankylostome et Trichuris trichiura, un par Trichuris trichiura seule et un par des vers nématodes (oxyures, ascaris). Quatre des treize cas étaient indemnés d'autres maladies.

Le traitement fut un succés dans neuf cas. Le reste des patients disparurent avant que la cure ne fût finie.

On pense que l'infestation par des vers parasites, surtout l'ankylostome, est plus fréquente en Grande Bretagne qu'il n'est généralement cru, et que les immigrants avec des symptômes minimes devraient être détectés en vue d'éliminer ces infestations. 